\title{
Hand hygiene techniques: still a requirement for evidence for practice?
}

\author{
L Price $^{1 *}$, J Reilly ${ }^{1}$, S Lang ${ }^{2}$, C Robertson ${ }^{3}$, F Cheater $^{4}$, A Chow $^{5}$ \\ From 3rd International Conference on Prevention and Infection Control (ICPIC 2015) \\ Geneva, Switzerland. 16-19 June 2015
}

\section{Introduction}

Two hand hygiene techniques are promoted internationally: the World Health Organisation's 6 step and the Centre for Disease Control's 3 step techniques; both of which may be considered to have suboptimum levels of empirical evidence for use with alcohol based hand rub (ABHR).

\section{Objectives}

The aim of the study was to to compare the effectiveness of the two techniques in clinical practice.

\section{Methods}

A prospective parallel group randomised controlled trial (RCT) was conducted with 1:1 allocation of 6 step versus the 3 step ABHR hand hygiene technique in a clinical setting. The primary outcome was residual microbiological load. Secondary outcomes were hand surface coverage and duration. The participants were medical and nursing participants $(\mathrm{n}=120)$ in a large teaching hospital.

\section{Results}

The 6 step technique was statistically more effective at reducing the bacterial count $1900 \mathrm{cfu} / \mathrm{ml}(95 \%$ CI 1300 , $2400 \mathrm{cfu} / \mathrm{ml})$ to $380 \mathrm{cfu} / \mathrm{ml}(95 \% \mathrm{CI} 150,860 \mathrm{cfu} / \mathrm{ml})$ than the 3 step $1200 \mathrm{cfu} / \mathrm{ml}(95 \% \mathrm{CI} 940,1850 \mathrm{cfu} / \mathrm{ml})$ to $750 \mathrm{cfu} /$ $\mathrm{ml}(95 \%$ CI $380,1400 \mathrm{cfu} / \mathrm{ml})(\mathrm{p}=0.016)$ but even with direct observation by two researchers and use of an instruction card demonstrating the technique, compliance with the 6 step technique was only $65 \%$, compared to $100 \%$ compliance with 3 step technique. Further those participants with 100\% compliance with 6 step technique had a significantly greater log reduction in bacterial load with no additional time or difference in coverage compared to those with $65 \%$ compliance with 6 step technique $(\mathrm{p}=0.01)$.

\section{Conclusion}

To our knowledge this is the first published RCT to demonstrate the 6 step technique is superior to the 3 step technique in reducing the residual bacterial load after hand hygiene using alcohol based hand rub in clinical practice. What remains unknown is whether the residual bacterial load after the 3 step technique is low enough to reduce risk of transmission from the hands and whether the 6 step technique can be adapted to enhance compliance in order to maximise reduction in residual bacterial load and reduce duration.

\section{Disclosure of interest}

None declared.

\section{Authors' details \\ 'Department of Nursing \& Community Health, Glasgow Caledonian University, Glasgow, UK. ²Department of Biological \& Biomedical Sciences, Glasgow Caledonian University, Glasgow, UK. ${ }^{3}$ Department Mathematics \& Statistics, Strathclyde University, Glasgow, UK. ${ }^{4}$ Faculty of Medicine and Health Sciences, University of East Anglia, Norwich, UK. ${ }^{5}$ Department of Clinical Epidemiology, Tan Tock Seng Hospital, Singapore, Singapore.}

Published: 16 June 2015

doi:10.1186/2047-2994-4-S1-049

Cite this article as: Price et al: Hand hygiene techniques: still a requirement for evidence for practice? Antimicrobial Resistance and Infection Control 2015 4(Suppl 1):049.

'Department of Nursing \& Community Health, Glasgow Caledonian

University, Glasgow, UK

Full list of author information is available at the end of the article 